\title{
Working Relations of the Village Head and the Village Consultative Body in the Village Funds Utilization
}

\author{
Muhammad Mukaddar'1), M Chairul Basrun Umanailo'2), Darwin Abd Radjak ${ }^{3)}$, Andries \\ Lionardo $^{4)}$ \& Nanik Handayani5)
}

1) Islamic Education, Islamic Faculty, Universitas Iqra Buru, Indonesia 2) Agrotechnology, Faculty of Agriculture and Foresty, Universitas Iqra Buru, Indonesia

3) Universitas Muhammadiyah Maluku Utara, Indonesia

4) Universitas Sriwijaya, Palembang, Indonesia

5) Institut Agama Islam Negeri Ambon, Maluku, Indonesia

Received: 04 June 2021; Reviewed: 04 June 2021; Acepted: 11 August 2021

*Corresponding Email: chairulbasrun@gmail.com

\begin{abstract}
This study aims to identify the relationship between the village head and the Village Consultative Body (BPD) in the use of village funds in the village of Karang Jaya, Namlea District, and explain the influence on the development of village communities. The problem is focused on the use of village funds which should be a stimulus for growth in each village, but, in management, there are often problems that hinder village development. This study seeks to see and get deeper into the relationship that has been built between the village head and the BPD in the village of Karang Jaya. The approach used in this study uses a qualitative approach. The number of informants who will be interviewed is 15 people taken purposively, considering that respondents are regarded as related parties to achieve the research objectives. Researchers used observational data collection techniques and in-depth interviews to obtain data on the implementation of the village fund program. The analysis technique used in this research is qualitative data analysis following the concepts given by Miles and Huberman, and Spradley. This study concludes that the parallel relationship pattern between the BPD and the village head in the management of the village government as regulated in the legislation, it turns out that in its implementation, there is enough response so that the working relationship becomes harmonious and leads to a pattern of cooperation and shows a tendency to share tasks that are parallel between the heads. Villages and BPD in the use of village funds.
\end{abstract}

Keywords: Village Head; Village Consultative Body; Village Fund; Karang Village.

How to Cite: Mukaddar, M., Umanailo, M.C.B., Radjak, D.A., Lionardo, A., \& Handayani, N., (2021). Working Relations of the Village Head and the Village Consultative Body in the Village Funds Utilization, Jurnal Administrasi Publik (Public Administration Journal). 11(2): 144-151 


\section{INTRODUCTION}

The Namlea Sub-district, which includes 11 villages and nine hamlets, is the administrative heart of the Rush District. The Namlea sub-district, with 226.55 square kilometers, is the most populous in Buru Regency. Karang Jaya Village is one of the villages in Namlea District's administrative region. The Namlea Subdistrict, which includes 11 villages and nine hamlets, is the administrative heart of the Rush District. The Namlea sub-district, with 226.55 square kilometers, is the most populous in Buru Regency. Karang Jaya Village is one of the villages in Namlea District's administrative region (BPS, 2020). These population growths will inevitably result in higher population density in Karang Jaya Village, which has implications for social problems that will be developing.

Traders and laborers with a medium level of education make up the majority of the population in this community. Karang Jaya Majority Village residents are Southeast Sulawesi migrants who have blended in with the Buru Island native population. 6.26 percent population growth rate. Along with the area's development, communities in the regions, mainly rural, continue to confront poverty, retardation, and difficulty obtaining public services. This situation raises awareness of rural populations' requirements for equal development and financial support from the government (APBN). The village's APBN allocation is expected to boost community engagement.

Village development has long been carried out with the help of the government, especially the allocation of village funds from $10 \%$ of APBD funds. However, with the ratification of Law Number 6 of 2014 concerning Desa, we can now do Village Development with village funds. Buru Regency has a total village fund budget of $65,863,399,000$. This is not a small amount if it is distributed to villages throughout the Buru Regency. But according to the mandate of permendes, village funds are prioritized for development and community empowerment spending.

Regarding the use of village funds, TANGKUKATI in research on the impact of the Village Fund Program shows that as long as the village fund program runs effectively in Pineleng Regency, it is necessary to strengthen the capacity and skills of the village government officials to support the implementation of the program to improve the economy. And the welfare of the people in the future. In addition, the relationship between village heads with BPD is essential to ensure the sustainability and implementation of the Village Fund Program optimally (Tangkumahat et al., 2017). While Daraba (2017) The research findings in Galesong Subdistrict showed that the participation of the village community began with the preparation of the RPJM, RKP Village, and APB (village), followed by the implementation of village development, and ended with the use of village development results. The Village Fund Program has a significant positive impact on the participation of village communities and relations between village stakeholders (Daraba, 2017). The results of other studies are Khaeril Anwar, who examine the working relationship between village heads and village consultation agencies by village law number 6 of 2014 . Responding to previous research, this study focuses on the relations of the work of the village head and BPD in the use of village funds. This relationship is interpreted as a pattern of partnership relations that can later assist in completing various problems in Karang Jaya Village. This research is expected to describe working ties between the two village institutions regarding village funds (Anwar, 2015). This research is expected to be able to give birth to a mapping document on the description of partnership relations that can be used as a reference for leaders in other villages

RESEARCH METHODS 
The study took place in Karang Jaya Village, Buru Regency's Namlea District. Choose the site intentionally. Karang Jaya Village was chosen as the study's site because it has people who reflect the Namlea District and indications of a sociocultural system and village geography. Karang Jaya Village is a village in a rush district dominated by the Southeast Sulawesi community, whose majority is a migrant who earns a living through trade and services (Bugis et al., 2019). The number of informants interviewed was fifteen people; they chose them intentionally to understand that they would be considered related parties to achieve research goals. The fifth of the informants consisted of village officials, members of the BPD, deputy community leaders, traditional leaders, and religious leaders, and community representatives who were considered competently related to the research objectives to be informants.

The data for this study were collected from primary sources in interviews with informants and secondary data in document analysis and observation. The researcher conducted in-depth interviews with these related parties to see their perspective on the relationship between the village head and the BPD regarding the use of the village budget. In addition, researchers conducted secondary research on the use of village funds in Namlea subdistrict via the internet (sinta.ristekbrin.go.id, garuda.ristekbrin.go.id

and Rama.ristekbrin.go.id), a literature study of government documents/archives related to policies village funds (Village Fund SmartBook, Priority for the Use of Village Funds in 2021, General Guidelines for the Implementation of the Use of Village Funds).

The analytical technique used is qualitative data analysis based on the concepts proposed by Miles and Huberman and Spradley. Qualitative data analysis is carried out interactively and continuously, from the beginning to the end of each research stage, and data analysis is carried out until the research is completed (N.K. Denzin, 2017). Researchers' analytical tasks include data reduction (data reduction), data presentation (data display), and conclusion drafting or verification. (conclusion drawing/ verification).

\section{RESULT AND DISCUSSION}

The village government carries out government affairs and represents the local community's interests in the Unitary State of the Republic of Indonesia (Akhmad \& Kusnida, 2020). This is decentralization in which authority is transferred from the central government to local governments to manage their household affairs, contrary to village communities' rights. At the village level, the government is led by a village head who has the authority and responsibility to manage his household through the administration of government and local government functions. The village head is responsible for administering village government, implementing village development, fostering village communities, and empowering village communities (Istiqomah, 2020; Jamaluddin et al., 2018; Qhilby et al., 2017). Through Law Number 16 of 2014 concerning villages, villages now have an excellent opportunity to manage their government and development to improve the community's welfare and quality of life. In addition, the village government is expected to be more independent in managing various village natural resources, including financial and wealth management (Heru Cahyono et al., 2020; Simbolon \& Sembiring 2015; Ngarsiningtyas \& Sembiring 2016).

The researcher interviewed K.G., one of the informants, who stated that in general development planning, analysis and identification are needed to describe the program planned to meet the 
development needs of Karang village. As a result, the Karang Jaya village government formed a special unit team (planning team) consisting of village officials and community members who have planningrelated resources to carry out analysis and identification related to development planning from short, medium, or long term development plans, which will then detailed in the village mid-term development plan (RPJMDes).

According to Thomas, management is a process or a series of tasks performed by a group of people that involve planning, organizing, implementing, and controlling to maximize the potential to achieve specific goals. According to Presidential Regulation Number 60 concerning Village Funds article 2, village funds are managed orderly, following applicable laws and regulations, efficient, economical, transparent, and responsible, while maintaining a sense of justice and decency and prioritizing the community's interests. The interests of the local community. Regarding Regulation of the Minister of Finance Number 49 concerning Allocations (Akhmad, Kusnida, 2020), Article 22 paragraph 2 of the distribution, use, monitoring, and evaluation of Village Funds reads, the implementation of activities financed from the Village Fund is prioritized to be carried out self-managed using local resources/raw materials and strived to absorb more labor from the local village community. (Sofiyanto et al., 2017).

In addition, it is stated that the village development planning of the Karang Jaya village government aims to improve the quality of life or community welfare. Village community empowerment is a process of identifying actions, programs, and policies that must implement to promote community independence and welfare by boosting knowledge, behavior, awareness, attitudes, skills, abilities, and resource utilization-adapted to the nature of the problem and the priority needs of the community. After speaking with village administrators and various community leaders, they believe that they can use village money to develop and empower rural communities to accomplish community welfare in Karang Jaya village. This statement was then agreed upon by the head of the BPD, who oversees the use of village funds and allocates funds to achieve village development goals, including improving welfare and quality of life and reducing poverty through meeting basic needs, building facilities, and infrastructure, and developing local economic potential.

Realizing that development activities are not merely physical but also involve the use of natural resources, which have the potential to change the existing ecosystem and have an impact, the following figure illustrates the mapping of proposals that took place between the village government and the village government and the BPD:

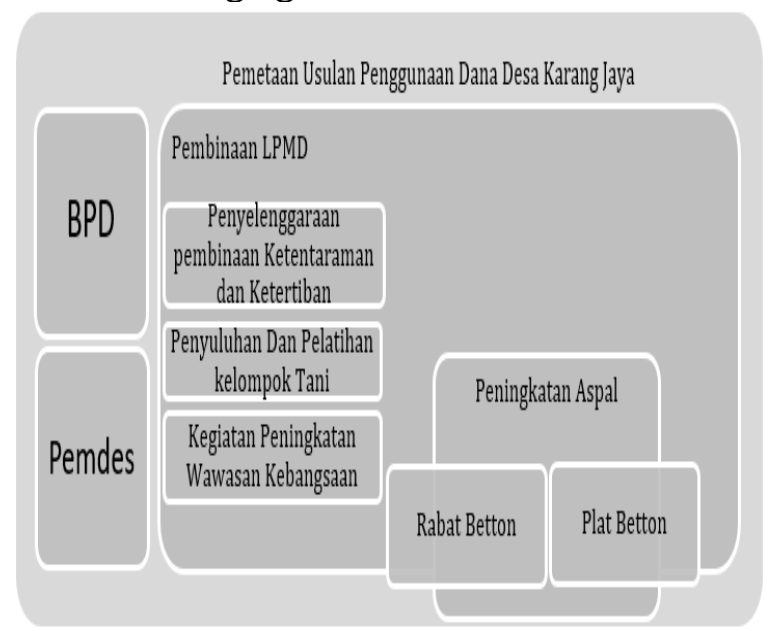

Gambar 1. Pemetaan Usulan Penggunaan Desa

Based on Figure 1, the Karang Jaya Village BPD prioritizes utilization in the development sector and community awareness, while the village government focuses on physical work planning. Based on the results of interviews, several parties expressed their opinions, including village heads, BPD heads, and community leaders, that the mapping of development planning through the use of village funds in Karang Jaya village refers to several conditions that exist in the town, the most significant of which is planning and implementation, 
Muhammad Mukaddar, M Chairul Basrun Umanailo, Darwin Abd Radjak, Andries Lionardo \& Nanik Handayani. Working Relations of the Village Head and the Village 'Consultative Body in the Village Funds

Utilization

which is all wrong. In addition, in carrying out its authority to regulate and manage the community's interests, the village consultative body functions as a legislative body (determining village policies). It accommodates and channels the aspirations of the community in collaboration with the village head. This institution is essentially a partner of the village government who has the same responsibility in administering village government, development, and community empowerment. The village consultative body as a legislative body has the authority to approve or disapprove of village policies taken by the village government.

The cooperative relationship that exists between the village government and the BPD is the division of labor. By comparing the designs for the use of village funds in Karang Jaya village, it is clear that the BPD prioritizes the use of village funds to improve skills and strengthen business capital. In contrast, the village government prioritizes strengthening business capital and organization-training and courses for entrepreneurs.

The pattern of parallel relations between the BPD and the village head in the administration of village governance, as required by law, clearly shows that there is an adequate response in practice to ensure a harmonious working relationship, resulting in a pattern of cooperation and a tendency to share parallel tasks between the village head and the village head. BPD. According to the researcher's observations, the kinship relationship between the BPD management and the village head is not always harmonious; the views or desires of the BPD proposed are often different from those of the village government, or vice versa. The following table details the organizational structure of the proposed village fund in Karang Jaya village.

Table 1 shows that the village government makes program proposals by the village government's work program, as stated by one of the informants (K.H.), who noted that the village government's bid to use village funds prioritized development proposals prepared previously. As for the $\mathrm{BPD}$, the proposal is an aspiration that is accommodated through deliberation and consensus carried out by several members of the BPD.

Table 1. Institutions Role in the Proposed Utilization of Village Funds

\begin{tabular}{lll}
\hline \multirow{2}{*}{$\begin{array}{l}\text { Institution } \\
\text { Village }\end{array}$} & \multicolumn{2}{c}{ Village Development } \\
\cline { 2 - 3 } & Planning & Implementation \\
\cline { 2 - 3 } & Increasinal strengthening BUMDes & Business capital assistance for BUMDes \\
\cline { 2 - 3 } & Increase people's reading interest & Course and Training \\
\cline { 2 - 3 } & Improve environmental quality & $\begin{array}{l}\text { Implementation of the “Clean Friday" initiative and Sunday social } \\
\text { services }\end{array}$ \\
\cline { 2 - 3 } & Filling village apparatus positions & Carry out elections and develop village structures \\
\cline { 2 - 3 } $\begin{array}{l}\text { Village } \\
\text { Representative } \\
\text { Body }\end{array}$ & Improving information services & make a wall magazine about village information \\
\cline { 2 - 3 } & Improving village economic resilience & Inventory of village financial resources \\
\cline { 2 - 3 } & Improving the economy of the poor & provide venture capital for Bundes \\
\cline { 2 - 3 } & Support environmental activities & carry out cooperation regularly \\
\cline { 2 - 3 } & Building a study group & Regular village recitation every Thursday \\
\hline
\end{tabular}

Source: Processing Data Primer Maret-Mei 2021

By observing the field data, we can conclude that there will be four distinct patterns of institutional relationships. These patterns are advantageous because they are accommodative, compromising, and reductive (half-hearted). To begin with, effective relationships require a balance of institutional and non-institutional factors. This effective relationship is possible if the executive (village head) and legislature 
(BPD) work together and are supported by a strong village head leadership style. In addition to the strong personality of the village head, the supporting constitutional structure is also strong (Wowor, 2015). The control of the internal parliament is also robust and follows the proportions mandated by the legislation that regulates it. In this situation of effective relations, the dynamics of government will lead to institutional strengthening. Second, the accommodative relationship is a condition where the institutional aspect is vital, but the non-institutional part is weak (Anwar, 2015). In this situation of effective relations, the dynamics of government will lead to institutional strengthening. Second, the accommodative relationship is a condition whThis form of relationship is formed when there is an executive who has a weak personality but can still be strengthened by a strong constitution and a strong support group. The condition of this accommodative relationship also occurs if the control of the parliament is proportional and by the body (Sidik, 2015). The bond between the two parties is also well tied because the same ideology and platform bind it. The tendency of this relationship, although accommodative, still allows the government to run effectively. Third, hostile relations are conditions when the institutional aspects (construction, design of political institutions, and party systems) are still fragile. Still, the personality and executive leadership style are strong, but the non-institutional aspect is weak.

This situation showed where the executive personality is firm but not supported by a robust institutional design while the control from the legislature is firm (legislative heavy). As a result, government stability is jeopardized. When the BPD and the Village Head come from opposite groups, ideologies, and platforms, or if they accommodate distinct interests, this confrontation ensues. It is vulnerable to impeachment on the executive role in this connection. The fourth reductive relationship is that the institutional condition is poor and is supported by an executive who is also weak. The state of personal weakness, the constitution, the soft structure, and the system of the administration and legislature make the legislature's control very powerful. This situation is related to the argumentative condition, in which the executive's disease tends to be strong even when the constitution is weak. Still, this reductive condition happens because the executive tends to be strong even when the body is soft. So the legislative position is very dominant (legislative heavy). The relationship between the two is also not based on a solid ideological bond (Rahayu, 2017). According to Solekhan, the village government is in charge of government matters, development, and society. Thus, when viewed functionally, the village government carries out the following functions: 1) managing village government affairs, 2) managing the development and community development, 3) managing village economic development, 4) managing development participation and cooperation, 5) managing development community peace and so on.

The village head and the BPD have a collaborative relationship founded on checks and balances for each institution's tasks and functions. As a result, village governance processes must create an environment conducive to a substantive democracy. Thus, the partnership relationship between the village head and the BPD must be based on mutual trust, cooperation, and mutual respect. If these three elements are present, the partnership will run harmoniously.

\section{CONCLUSION}

The relationship between the village government and the village consultative body is intended in this study as a collaborative effort in the development and implementation of village funds and 
Muhammad Mukaddar, M Chairul Basrun Umanailo, Darwin Abd Radjak, Andries Lionardo \& Nanik Handayani. Working Relations of the Village Head and the Village 'Consultative Body in the Village Funds Utilization

collaborative efforts in the administration of village governance, especially collaborative efforts between the village head and the village consultative body. The functioning of the institution following its embodiment as an institution that carries out tasks from planning to implementation, as well as the existence of an institution that selects planning and also oversees implementation, so that village heads have a working relationship with the BPD in terms of determining policies and determining the use of funds, is the articulation of the relationship. Villages that the BPD has approved.

\section{ACKNOWLEDGMENTS}

The authors would like to express their gratitude to the Directorate of Research and Community Service of the Ministry of Research, Technology, and Higher Education for providing research opportunities through the 2021 Beginner Lecturer Research scheme grant. In addition, the authors also thank the Chairperson of the Institute for Research and Community Service (LPPM), Head of the Center for Planning Studies Community Development (PSP2M) Iqra Buru University for the support provided during the research and writing of this article to completion.

\section{REFERENCES}

Akhmad, Kusnida, N. (2020). Implementasi UndangUndang Republik Indonesia Nomor 6 Tahun 2014 Tentang Desa (Studi Pada Fungsi Badan Permusyawaratan Desa Di Desa Bintang Ninggi II Kecamatan Teweh Selatan Kabupaten Barito Utara). Jurnal Administrasi Publik, 6(1), 10-15.

Anwar, K. (2015). Hubungan Kerja Antara Kepala Desa Dengan Badan Permusyawaratan Desa ( Bpd ) Menurut Undang-Undang Nomor 6 Tahun 2014 Tentang Desa Working Relation Between Head of the Village and Consultative Body of the Village ( Bpd ) According To Law. IUS Kajian Hukum Dan Keadilan, III(8), 207222.

https://jurnalius.ac.id/ojs/index.php/jurnall US/article/view/208/182
Badan Pusat Statistik (BPS). (2020). Kabupaten Buru dalam Angka 2020. In Badan Pusat Statistik Kabupaten Buru.

Bugis, R., Malik, S., Kurniawan, R., Chairul, M., Umanailo, B., Hehamahua, H., \& Iqra Buru, U. (2019). Rongo-Rongo Dalam Pemenuhan Kebutuhan Rumah Tangga. In JISPO (Vol. 9, Issue 2).

Daraba, D. (2017). Pengaruh Program Dana Desa Terhadap Tingkat Partisipasi Masyarakat di Kecamatan Galesong Utara Kabupaten Takalar. Sosiohumaniora. https://doi.org/10.24198/sosiohumaniora.v 19i1.11524

Heru Cahyono, Aziz, N. L. L., Nurhasim, M., Rahman, A. R., \& Zuhro, R. S. (2020). Pengelolaan Dana Desa Studi dari Sisi Demokrasi dan Kapasitas Pemerintahan Desa. In Lembaga Ilmu Pengetahuan Indonesia (LIPI). LIPI Press. https://www.kemenkeu.go.id/media/6749/ buku-pintar-dana-desa.pdf

Istiqomah, N. L. (2020). Peran Badan Permusyawaratan Desa (Bpd) Dalam Pengawasan Penggunaan Dana Desa, di Desa Daseh Kecamatan Pakis Kabupaten Magelang Periode 2018 [Institut Agama Islam Negeri (Iain) Salatiga]. In Institut Agama Islam Negeri (IAIN) SALATIGA 2020 (Vol. 21, Issue 1). http://erepository.perpus.iainsalatiga.ac.id/9944/1/ skripsi gabungan.pdf

N.K. Denzin, Y. S. L. (2017). Turning Points In Qualitative Research. In ALTAMIRA PRES (Vol. 91).

Rahayu, D. D. (2017). Dinamika Relasi Kepala Desa dan Badan Permusyawaratan Desa (BPD) [Brawijaya]. http://repository.ub.ac.id/5624/1/Rahayu \%2C Dina Dwi.pdf

Sidik, F. (2015). Menggali Potensi Lokal Mewujudkan Kemandirian Desa. JKAP (Jurnal Kebijakan Dan Administrasi Publik). https://doi.org/10.22146/jkap.7962

Sofiyanto, M., Mardani, R. M., \& Salim, M. G. (2017). Pengelolaan Dana Desa Dalam Upaya Meningkatkan Pembangunan Di Desa Banyuates Kecamatan Banyuates Kabupaten Sampang. Jurnal Riset Manajemen, November 2016, 124-135. http://riset.unisma.ac.id/index.php/jrm/iss ue/view/85

Tangkumahat, F. V., Panelewen, V. V. J., \& Mirah, A. D. P. (2017). Dampak Program Dana Desa Terhadap Peningkatan Pembangunan dan Ekonomi di Kecamatan Pineleng Kabupaten Minahas. Agri-Sosioekonomi. https://doi.org/10.35791/agrsosek.13.2a.20 17.17130 
Wowor, S. (2015). Peran Badan Permusyawaratan Desa (BPD) Dalam Demokratisasi Pemerintahan Desa.

Jamaluddin, Y. Sumaryana, A. Rusli, B. \& Buchari, R.A. (2018). Analisis Dampak Pengelolaan dan Penggunaan Dana Desa terhadap Pembangunan Daerah. JPPUMA: JPPUMA: Jurnal Ilmu Pemerintahan dan Sosial Politik UMA (Journal of Governance and Political UMA), 6 (1): 14-24.

Qhilby, Tarigan, U, Dewi, R (2017). Peranan Badan Permusyawaratan Desa dalam Perencanaan Pembangunan Desa. PERSPEKTIF, 6 (2): 4152.
Simbolon, A.H., dan Sembirng, W.M., (2015). Evaluasi Kinerja Badan Permusyawaratan Desa dalam Penyelenggaraan Pemerintahan Desa, JPPUMA: Jurnal Ilmu Pemerintahan dan Sosial Politik UMA (Journal of Governance and Political UMA), 1 (1): 143-159.

Ngarsiningtyas, S.K., dan Sembiring, W.M., (2016) Peran Badan Permusyawaratan Desa dalam Penyusunan dan Penetapan Peraturan Desa, JPPUMA: Jurnal Ilmu Pemerintahan dan Sosial Politik UMA (Journal of Governance and Political UMA), 4 (2): 159-172. 